\title{
Propagating arbuscular mycorrhizal fungi associated with coffee plant by using the herbaceous host
}

\author{
Dang Hoang Quyen ${ }^{1 *}$, Vu Thuy Duong ${ }^{1}$, Pham Nguyen Duc Hoang ${ }^{1}$ \\ ${ }^{1}$ Ho Chi Minh City Open University, Vietnam \\ *Corresponding author: dhquyendl@gmail.com
}

\begin{tabular}{|c|c|}
\hline ARTICLE INFO & ABSTRACT \\
\hline $\begin{array}{l}\text { DOI: } 10.46223 / \text { HCMCOUJS. } \\
\text { tech.en.8.1.338.2018 }\end{array}$ & $\begin{array}{l}\text { Coffee (Coffea spp.) is one of the important industrial crops. } \\
\text { Additionally, arbuscular mycorrhizal fungi (AMF) provide many } \\
\text { benefits for plants such as increasing nutrient uptake, enhancing } \\
\text { tolerance in drought and stress conditions, etc. Therefore, the } \\
\text { preservation and propagation of AMF spores collected from } \\
\text { coffee's rhizosphere are necessary for coffee cultivation. The }\end{array}$ \\
\hline Received: February $6^{\text {th }}, 2018$ & AMF preservation on the coffee plant is not feasible because \\
\hline Revised: March 22 $2^{\text {nd }}, 2018$ & coffee is a long-term plant, which led to studying on the symbiotic \\
\hline Accepted: April $16^{\text {th }}, 2018$ & $\begin{array}{l}\text { ability of AMF on several short-term host plants (maize (Zea } \\
\text { mays), plantain (Plantago spp.), rice (Oryza sativa), beggarticks } \\
\text { (Bidens pilosa), and bahiagrass (Pensacola bahia)) to maintain } \\
\text { AM association. Investigation of symbiosis ability with four types } \\
\text { of AMF spores showed that maize had the highest rate of fungal } \\
\text { infection. The total number of AMF spores per } 50 \mathrm{~g} \text { soil after } 3\end{array}$ \\
\hline Keywords: & months of inoculation on maize reached 352 spores, which was \\
\hline $\begin{array}{l}\text { AMF, coffee, maize, } \\
\text { propagation, symbiosis }\end{array}$ & $\begin{array}{l}\text { 4.1 times higher than that of the origin while the lowest figure } \\
\text { recorded in Bahia grass is with only } 2.3 \text { times. }\end{array}$ \\
\hline
\end{tabular}

\section{Introduction}

Arbuscular mycorrhizal fungi (AMF) are the most symbiotic species on earth. AMF can associate with $80 \%$ of plant species (Strack, Fester, Hause, Schliemann, \& Walter, 2003). The first AMF detection of AMF was recorded in 1842 (Nageli, 1842). Until now, the role of AMF has been recorded in many studies. The main AMF benefits have been reported as the increase in nutrient uptake, resistance to stress and drought conditions (Auge', 2001, 2004), tolerance to pathogens (Elsen, Baimey, Swennen, \& De Waele, 2003; Vaast, Caswell, \& Zasoski, 1998).

On the other hand, coffee (Coffea spp.) is an industrial plant that has worldwide economic importance. Coffee creates a significant source of income for developing countries. The genus Coffea belongs to the Rubiaceae family, which includes about 100 species (Davis, Govaerts, Bridson, \& Stoffelen, 2006), only two species are commercially cultivated, Coffea arabica and Coffea canephora. Vietnam is the second-largest coffee producer in the world, especially Coffea canephora. Coffee is affected directly or indirectly by millions of jobs in the Tay Nguyen area and other provinces such as Dong Nai, Binh Phuoc, Son La, and Quang Tri. 
However, the quality and productivity of coffee haven't still stabilized. In 1987, Janse observed the presence of AMF in the coffee plant. After that, there are many studies about the diversity, distribution, the role of AMF in coffee plants, but mostly in Africa and Latin America. In Vietnam, the preservation of native AMF from coffee plants is very important. This AMF source will be used for serving the coffee industry. Host plants that have been successfully used to propagate AMF include alfalfa, corn, soybean, white clover, onion, sudangrass, bahiagrass, narrow leaf plantain, marigold (Corkidi, Evans, \& Bohn, 2008). However, these host plants can affect the sporulation of AMF communities (Bever, Morton, Antobovics, \& Schultz, 1996). For example, Gigaspora sinuosum and G. clavisporum do not produce spores when using the trapplant Sorghum vulgare (Guadarrama, Camargo, Hernández, \& Castillo, 2007). Therefore, our research suggests the surveys of different host herbaceous plants to choose the best one for propagating AMF.

\section{Materials and methods}

\subsection{Preparing AMF spore}

AMF spore: AMF spores were extracted from the soil collected from the rhizosphere under the coffee canopy by the wet sieving (Gerdemann \& Nicolson, 1963) and sucrose density gradient centrifugation technique (Daniels \& Skipper, 1982). This mixture is including B7, O3, O5, RE7, RE10, W6, Y3, Y5 (Table 1).

\section{Table 1}

AMF spore phylotypes were used in this study

\begin{tabular}{|c|c|c|c|c|c|}
\hline Code & Color, shape & Photo & Code & Color, shape & Photo \\
\hline B7 & Brown, globose & & RE7 & $\begin{array}{l}\text { Dark red, } \\
\text { globose }\end{array}$ & \\
\hline $\mathbf{O 3}$ & $\begin{array}{l}\text { Orange, } \\
\text { globose }\end{array}$ & & W6 & $\begin{array}{l}\text { White, } \\
\text { globose }\end{array}$ & \\
\hline 05 & $\begin{array}{l}\text { Orange - red, } \\
\text { oval }\end{array}$ & & Y3 & $\begin{array}{l}\text { Yellow, } \\
\text { globose }\end{array}$ & \\
\hline
\end{tabular}




\begin{tabular}{|c|l|l|l|l|l|}
\hline Code & Color, shape & Photo & Code & Color, shape & Photo \\
\hline RE10 & $\begin{array}{l}\text { Red - brown, } \\
\text { globose }\end{array}$ & & Y5 & $\begin{array}{l}\text { Yellow, } \\
\text { globose }\end{array}$ & \\
\hline
\end{tabular}

Source: The researcher's data analysis

\subsection{Preparing potting soil}

Soil and sand (1:1 v/v) were mixed and autoclaved before the experiment. Each pot (19 $\mathrm{cm}$ diameter and $14 \mathrm{~cm}$ in height) was sterilized by ethanol $70^{\circ}$. Adding AMF spores into mixed soil and sand. Then put all of them into the pot.

\subsection{Treating seed}

Seeds of coffee (C. arabica and C. canephora), maize (Zea mays), plantain (Plantago spp.), rice (Oryza sativa), beggarticks (Bidens pilosa), and bahiagrass (Pensacola bahia) were sterilized with $3 \% \mathrm{NaOCl}$ in 2 mins and rinsed with sterilized water before sowing.

\subsection{Inoculation}

Coffee seeds were sown into sterilized sand to prepared clam-leaf seedlings. Five seedlings were planted in each potting soil containing 8 AMF spore phylotypes. After 3 months, extracted and counted AMF spore from $50 \mathrm{~g}$ soil and compared with the original quantity.

AMF phylotypes associated with coffee plants were mixed and added to potting soil, sowing five seeds of each herbaceous plant in a pot. After 3 months, extracted and counted AMF spore from $50 \mathrm{~g}$ soil and compared with original quantity to choose the best host for propagating AMF. Collecting roots to evaluate the rate of fungal infection.

\subsection{Rate of fungal infection}

Fragmental roots (2-4 cm long segments) were soaked in $\mathrm{H}_{2} \mathrm{O}_{2}$ for 2-3 minutes to remove phenolic compounds; washed again with $10 \% \mathrm{KOH}$ overnight and boiled for about 30 60 minutes in boiling water. After that, all fragmental roots were soaked in 5\% lactic acid solution for 3-5 minutes; stained in Trypan blue for 10-15 minutes, washed again with the lactoglycerol solution and immersed in 50\% glycerol. The roots were observed under the microscope in a $20 \%$ glycerol mounting solution. The gridline intersection method was used to calculate the fungal infection rate.

\subsection{Data analysis}

All data is recorded, stored and processed by MS Excel 2013 software (Microsoft, WA, United States). Independent means were compared using an independent t-test LSD $(\alpha=0.05)$. 


\section{Results and discussion}

\subsection{AMF phylotypes associated with coffee plants}

After 3 months of inoculating a mixture of AMF spores into potting soil for associating with coffee plants, only the quantity of four in eight phylotypes (O5, W6, Y3, Y5) increased compared with that of the origin (Table 2). Other phylotypes decreased or died (B7, O3, RE10, RE7). Between $C$. arabica and $C$. canephora, the association of different AMF phylotypes to host plant is different. There was a significant difference between two coffee species about Y5 phylotype. The root of $C$. canephora associated with Y5 spores stronger than C. arabica. Therefore, a significant difference was observed between the average of Y5 spores number of C. canephora (244 spores/50g soil) and C. arabica (71 spores/50g soil).

\section{Table 2}

Number of AMF spores per 50g soil after 3 months of inoculation on coffee plants (Different letters within rows show significantly difference)

\begin{tabular}{|l|c|c|c|}
\hline \multicolumn{1}{|c|}{ Spore code } & Origin & C. arabica & C. canephora \\
\hline B7 & $75^{\mathrm{a}} \pm 9$ & $0^{\mathrm{b}} \pm 0$ & $0^{\mathrm{b}} \pm 0$ \\
\hline O3 & $38^{\mathrm{a}} \pm 8$ & $0^{\mathrm{c}} \pm 0$ & $1^{\mathrm{b}} \pm 0$ \\
\hline O5 & $8^{\mathrm{b}} \pm 1$ & $45^{\mathrm{a}} \pm 23$ & $59^{\mathrm{a}} \pm 10$ \\
\hline RE10 & $20^{\mathrm{a}} \pm 1$ & $0^{\mathrm{c}} \pm 0$ & $4^{\mathrm{b}} \pm 2$ \\
\hline RE7 & $17^{\mathrm{a}} \pm 2$ & $1^{\mathrm{b}} \pm 1$ & $4^{\mathrm{b}} \pm 2$ \\
\hline W6 & $25^{\mathrm{b}} \pm 8$ & $94^{\mathrm{a}} \pm 38$ & $135^{\mathrm{a}} \pm 74$ \\
\hline Y3 & $2^{\mathrm{b}} \pm 0$ & $26^{\mathrm{a}} \pm 15$ & $31^{\mathrm{a}} \pm 9$ \\
\hline Y5 & $33^{\mathrm{b}} \pm 9$ & $71^{\mathrm{b}} \pm 38$ & $244^{\mathrm{a}} \pm 102$ \\
\hline Total of spore & $\mathbf{2 1 9}$ & $\mathbf{2 3 6}$ & $\mathbf{4 7 8}$ \\
\hline
\end{tabular}

Source: The researcher's data analysis

The rate of four phylotypes O5, W6, Y3, Y5 was 68/219. After three months, the spore quantities were recorded on $C$. arabica (235 spores) and $C$. canephora (478 spores) that were higher than 3.5 and 7 times respectively in comparison with that in the previous soil. Those results indicated that four phylotypes can associate with coffee plants and produce new spores in greenhouse conditions.

\subsection{AMF associated with herbaceous host plants}

Using four phylotypes of spore (O5, W6, Y3, Y5) with a total number of 85 spores/50 $\mathrm{g}$ soil for inoculating with five herbaceous plants. After 3 months, the results showed that the maize plant was the best host (Table 3). The total spore after 3 months inoculating on the maize plant reached 352 spores. Maize plant has a high ability in association with 3 phylotypes of 
spore (W6, Y3, Y5). Only with O5 phylotype, the number of spores was insignificantly different from the origin.

\section{Table 3}

Number of AMF spore per $50 \mathrm{~g}$ soil after 3 months of inoculation on herbaceous plants (Different letters within rows show significantly difference)

\begin{tabular}{|l|c|c|c|c|c|c|}
\hline AMF phylotype & Origin & Plantago spp. & Z. mays & O. sativa & B. pilosa & P. bahia \\
\hline O5 & $16^{\mathrm{b}} \pm 9$ & $17^{\mathrm{b}} \pm 8$ & $16^{\mathrm{b}} \pm 8$ & $38^{\mathrm{a}} \pm 18$ & $15^{\mathrm{bc}} \pm 5$ & $3^{\mathrm{c}} \pm 1$ \\
\hline W6 & $40^{\mathrm{c}} \pm 1$ & $112^{\mathrm{b}} \pm 42$ & $206^{\mathrm{a}} \pm 58$ & $128^{\mathrm{b}} \pm 100$ & $109^{\mathrm{bc}} \pm 34$ & $101^{\mathrm{bc}} \pm 21$ \\
\hline Y3 & $2^{\mathrm{b}} \pm 0$ & $15^{\mathrm{a}} \pm 13$ & $14^{\mathrm{a}} \pm 6$ & $10^{\mathrm{ab}} \pm 2$ & $17^{\mathrm{a}} \pm 7$ & $16^{\mathrm{a}} \pm 2$ \\
\hline Y5 & $27^{\mathrm{b}} \pm 8$ & $109^{\mathrm{a}} \pm 35$ & $116^{\mathrm{a}} \pm 62$ & $91^{\mathrm{a}} \pm 30$ & $85^{\mathrm{a}} \pm 53$ & $75^{\mathrm{ab}} \pm 14$ \\
\hline Total of spore & $\mathbf{8 5}$ & $\mathbf{2 5 3}$ & $\mathbf{3 5 2}$ & $\mathbf{2 6 8}$ & $\mathbf{2 2 6}$ & $\mathbf{1 9 5}$ \\
\hline
\end{tabular}

Source: The researcher's data analysis

Rice plant also associated effectively with 3 phylotypes of spore (O5, W6, Y5). However, the total spore after 3 months of inoculating reached 268 spores. Three phylotypes of spore (W6, Y3, Y5) could associate effectively with plantain plant and the total of spore after 3 months of inoculation reached 253 spores. On beggarticks plant, the association with AMF showed to be lower than that in maize, rice and plantain. It could associate effectively with Y3 and Y5 spore phylotype. The lowest association is Bahia grass plant, only one spore phylotype (Y3) has a significant difference from the origin and the total average of spore was 195 spores, higher than that of the original only 2.3 times. Plantain, maize, and rice are often selected to propagating AMF, the association with AMF is higher than beggarticks and bahiagrass. Although beggarticks and bahiagrass appear frequently on the coffee farm, their AMF association and propagation were not effective. Some previous studies showed that Zea mays was the best host plant. When using Mimosa invisa, Sorghum bicolor and Zea mays on AMF propagation, resulted from spore population and root colonization were recorded at the highest rate on Z. mays (3690 spores/100 $\mathrm{cm}^{3}$ and $65 \%$ root length colonized) (Chaiyasen, Leardwiriyakool, David, \& Saisamorn, 2016). The research of Selvakumar et al. (2016) also showed the same results. Mycorrhizal inoculation by trap culture in maize resulted in longer shoots and roots than sudangrass plants and after the second plant cycle, maize plants had a higher percentage of mycorrhizal response in terms of colonization and arbuscules than sudangrass (Selvakumar et al., 2016). Therefore, the maize plant was selected as the best host plant for propagating AMF spore collected from the coffee rhizosphere.

\subsection{Rate of AMF infection on herbaceous plants}

The root of different plants which collected after 3 months inoculated with the mixture of AMF spore was treated and stained with Trypan blue (2.5). The rate of fungal infection was shown in Figure 1. The results showed that the highest rate of fungal infection (67\%) was observed in maize meanwhile the lowest one was reported in beggarticks (15\%). These certificated above results, the associated ability of maize root with AMF higher than others, the 
root colonization in maize was also higher. Root colonization was mainly influenced by the host plant and soil texture, the first factor being responsible for the highest differences. The highest root colonization percentages observed in maize could be due to higher compatibility between the presence of AMF in the inoculum and the plant (Carrenho, Sandra, Vera, \& Eraldo, 2007).

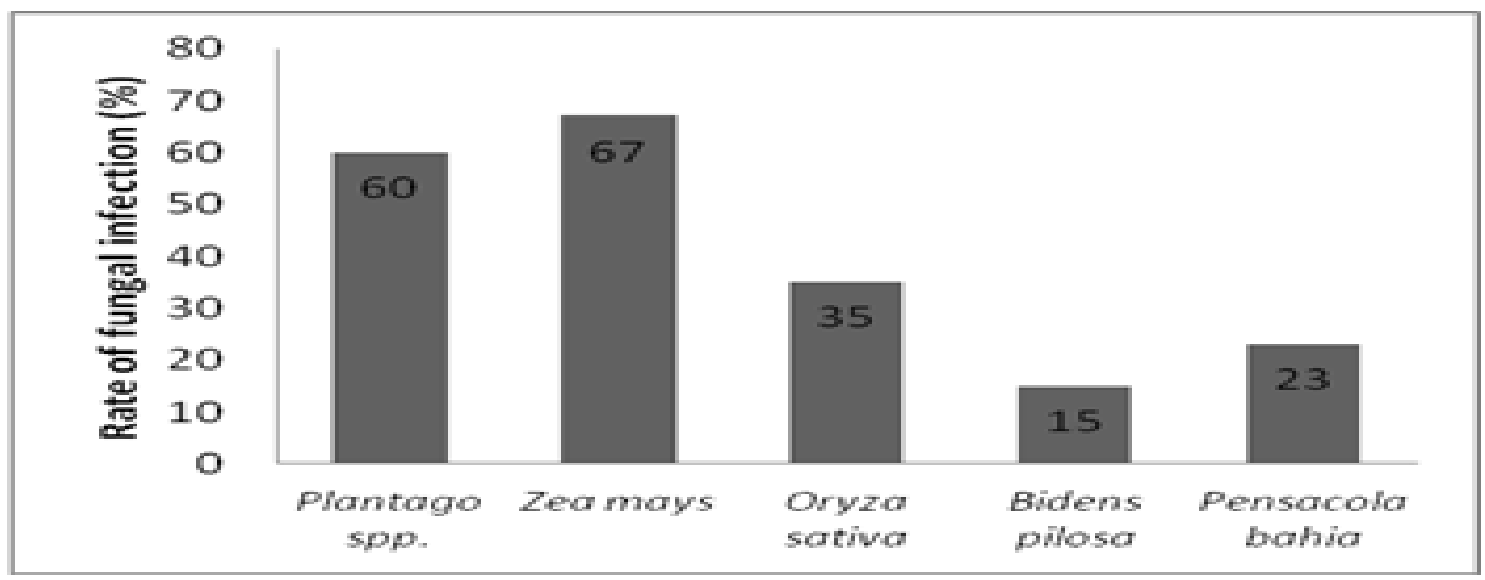

Figure 1. Rate of fungal infection on herbaceous plants

\section{Conclusion}

In greenhouse condition, there were only 4 AMF spore phylotypes having an increase of AMF quantity (O5, W6, Y3, Y5) after 3 months of inoculation on the coffee plants. When using these AMF phylotypes for the experiment on herbaceous host plants, both AMF quantity and rate of fungal infection showed that the best inoculation on Zea mays. Therefore, Zea mays were selected as the host plant for propagating and preserving AMF.

\section{ACKNOWLEDGEMENTS}

The research was supported by the Biotechnology Center of Ho Chi Minh City.

\section{References}

Auge', R. M. (2001). Water relations, drought and vesicular-arbuscular mycorrhizal symbiosis. Mycorrhiza, 11, 3-42.

Auge', R. M. (2004). Arbuscular mycorrhizae and soil plant water relations. Canadian Journal of Soil Science, 84, 373-381.

Bever, J. D., Morton, J. B., Antobovics, J., \& Schultz, P. (1996). Host dependent sporulation and species diversity of arbuscular mycorrhizal fungi in a mown grassland. Journal of Ecology, 84, 71-82.

Brundrett, M., Bougher, N., Dell, B., Grove, T., \& Malajczuk, N. (1996). Working with mycorrhizas in forestry and agriculture. Monograph, Australian: Australian Centre for International Agricultural Research. 
Carrenho, R., Sandra, F. B. T., Vera, L. R. B., \& Eraldo, S. S. (2007). The effect of different soil properties on arbuscular mycorrhizal colonization of peanuts, sorghum and maize. Acta Botanica Brasilica, 21(3), 723-730.

Chaiyasen, A., Leardwiriyakool, C., David, D. D., \& Saisamorn, L. (2016). Influence of host plants and soil diluents on arbuscular mycorrhizal fungus propagation for on farm inoculum production using leaf litter compost and agrowastes. Biological Agriculture \& Horticulture, 33(1), 1-11. doi:10.1080/01448765.2016.1187670

Corkidi, L., Evans, M., \& Bohn, J. (2008). An introduction to propagation of arbuscular mycorrhizal fungi in pot cultures for inoculation of native plant nursery stock. Native Plants Journal, 9(1), 29-38.

Daniels, B. A., \& Skipper, H. D. (1982). Methods for recovery and quantitative estimation of propagules from soil. In N. C. Schenck (Ed.), Methods and principles of mycological research. Saint Paul, MN: The American Phytological Society.

Davis, A. P., Govaerts, R., Bridson, D. M., \& Stoffelen, P. (2006). An annotated checklist of the genus Coffea L. (Rubiaceae). Botanical Journal of the Linnean Society, 152(4), 465512.

Elsen, A., Baimey, H., Swennen, R., \& De Waele, D. (2003). Relative mycorrhizal dependency and mycorrhiza-nematode interaction in Banana cultivars (Musa spp.) differing in nematode susceptibility. Plant and Soil, 256, 303-313.

Gerdemann, J. W., \& Nicolson, T. H. (1963). Spores of mycorrhizal Endogone species extracted from soil by wet sieving and decanting. Transaction of the British Mycological Society, 46(2), 235-244.

Guadarrama, C. P., Camargo, R. S. L., Hernández, C. L., \& Castillo, A. S. (2007). Los hongos micorrizógenos arbusculares de la región de Nizanda, Oaxaca, México. Boletín de la Sociedad Botánica de México, 81(81), 131-137.

Johnson, N. C., Tilman, D., \& Wedin, D. (1992). Plant and soil controls on mycorrhizal fungal communities. Ecology, 73, 2034-2042.

Nageli, C. (1842). Pilze im innern von zellen. Linnaea, 16, 278-285.

Selvakumar, G., Kiyoon, K., Denver, W., Mak, C., Yeongyeong, K., Bongnam, C., \& Tongmin, S. (2016). Trap culture technique for propagation of arbuscular mycorrhizal fungi using different host plants. Korean Journal of Soil Science and Fertilizer, 49(5), 608-613.

Strack, D., Fester, T., Hause, B., Schliemann, W., \& Walter, M. H. (2003). Arbuscular mycorrhiza: Biological, chemical, and molecular aspects. Journal of Chemical Ecology, 29(9), 1955-1979.

Vaast, P., Caswell, C. E. P., \& Zasoski, R. J. (1998). Influences of a root-lesion nematode, Pratylenchus cof-feae, and two arbuscular mycorrhizal fungi, Acaulospora mellea and Glomus clarum on coffee (Coffea arabica L.). Biology and Fertility of Soils, 26, 130-135. 